\title{
Bio-Electro-Fenton: a novel method for treating leachate in Da Phuoc Landfill, Vietnam
}

\author{
Ho Nhut Linh, Ho Truong Nam Hai*
}

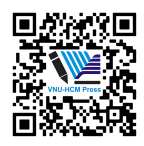

Use your smartphone to scan this QR code and download this article

Faculty of Environment, University of Science, Vietnam National University - Ho Chi Minh City

Correspondence

Ho Truong Nam Hai, Faculty of Environment, University of Science, Vietnam National University - Ho Chi Minh City

Email: htnhai@hcmus.edu.vn

History

- Received: 2019-12-14

- Accepted: 2020-02-17

- Published: 2020-03-19

DOI : 10.32508/stdj.v23i1.1736

\section{Check for updates}

\section{Copyright}

(c) VNU-HCM Press. This is an openaccess article distributed under the terms of the Creative Commons Attribution 4.0 International license.

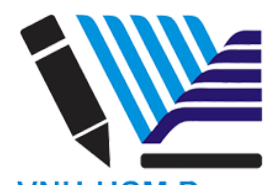

VNU-HCM Press

\begin{abstract}
Introduction: Leachate is a noticeable pollution problem because it contains a considerable amount of persistent organic pollutants (POPs). If leachate isn't treated thoroughly, its leak will negatively affect the environment. Therefore, appropriate treatment technologies are required to remove them. Bio-Electro-Fenton (BEF) is a new method using microorganisms such as electrolytes to convert chemical energy into electricity to help create $\mathrm{H}_{2} \mathrm{O}_{2}$ support advanced oxidation process (AOPs). Realizing the potentials that BEF brings, this study applies BEF to assess the effectiveness of leachate treatment at Da Phuoc landfill (operation period > 12 years), Ho Chi Minh City, which to save costs and energy for Fenton process. Methods: The BEF pilot scale model $(30 \times 10 \times 10 \mathrm{~cm})$ is divided by a proton exchange membrane (PEM) (Nafion 112) into two chambers (anode and cathode). Cathode chamber used a graphite electrode, the anode chamber used a carbon fabric electrode. The experiments aimed to determine the optimal conditions of parameters affecting the BEF system by determining the efficiency of $\mathrm{COD}$ removal and $\mathrm{BOD}_{5} / \mathrm{COD}$ ratio in leachate. Results: At optimal conditions of the model including $\mathrm{pH} 3$, $\left[\mathrm{Fe}^{2+}\right]=4 \mathrm{~g} / \mathrm{L}$, current intensity $=1 \mathrm{~A}$, reaction time 60 minutes and airflow $=12 \mathrm{~L} / \mathrm{min}$, as a result COD was reduced by $68.2 \pm 1.04 \%$ from $4950 \pm 14 \mathrm{mgO}_{2} / \mathrm{L}$ to $1574.1 \pm 51.4 \mathrm{mgO}_{2} / \mathrm{L}$, the ratio of $\mathrm{BOD}_{5} / \mathrm{COD}=0.1$ Conclusion: The study result showed thatBio-electro-Fenton process is effective for wastewater with high concentrations of pollutant and difficult to treat as leachate suggesting that the appropriate method for pre-treatment processes support the thorough elimination of pollutants.

Key words: Leachate, Bio-Electro-Fenton, AOPs, treatment.
\end{abstract}

\section{INTRODUCE}

The population explosion and industrialization in recent years have increased the demand for consumption of goods, materials, and energy which leads to a rapidly increasing amount of domestic waste generated. According to the estimation of The National Environment Statistics report in 2017 of The Ministry of Natural Resources and Environment, the amount of domestic solid waste in urban areas increases by an average of $10-16 \%$ per year. The majority of domestic waste in Vietnam has been treated by the landfill method. When using this method, a considerable amount of leachate will be generated, which does harm to the environment because leachate contains heavy metals, ammonium, and POPs. The composition and characteristics of leachate are complicated by seasonal changes and burial time hence leachate treatment is extremely sophisticated.

There are many different methods for treating leachate such as flocculation, adsorption, oxidation, etc. AOPs are the most outstanding treatment method which form hydroxyl $\left({ }^{\bullet} \mathrm{OH}\right)$ free radicals to decompose organic pollutants base on characteristics such as non-selective pollutants oxidation, easily react at room temperature. Typical AOPs such as tradition Fenton and Electro-Fenton have been proven to efficiently treat leachate. However, the traditional Fenton process requires the supply of a large amount of $\mathrm{H}_{2} \mathrm{O}_{2}$ and $\mathrm{Fe}^{2+}$. Besides the amount of reagent added is unstable and requires partial treatment of the chemicals remain after the reaction. For Electro-Fenton, the process requires large energy for the generation of $\mathrm{H}_{2} \mathrm{O}_{2}$. To deal with these disadvantages, it is necessary to progress a low-cost Fenton process which ensures treatment efficiency, therefore BEF method was invented. The BEF method uses microorganisms to decompose organic matter creating energy to form $\mathrm{H}_{2} \mathrm{O}_{2}$ for Fenton processes. As a result of the BEF method is a multipurpose method which save costs by reducing electrical energy consumption and using chemicals.

The BEF is a completely new technology. In Vietnam, there has not been any previous article about BEF application in wastewater treatment. Therefore, in this study, we optimize the parameters affecting the BEF method in a complex matrix, with the purpose of 
evaluating the applicability of the method in leachate treatment. The experiments had been conducted to find optimal conditions through COD treatment efficiency and $\mathrm{BOD}{ }_{5} / \mathrm{COD}$ ratio of leachate.

\section{MATERIALS AND METHODS}

\section{Sampling}

Samples had collected at the Da Phuoc Solid Waste Treatment Complex in Ho Chi Minh City in March 2019. Sampling, transportation, and preservation techniques complied with TCVN 5999: 1995. Samples had precipitated and stored in 2 plastic containers 30L.

According to Table 1, leachate has neutral $\mathrm{pH}$, COD is $4950 \mathrm{mgO}_{2} / \mathrm{L}, \mathrm{BOD}_{5}$ is $1500 \pm 59.7 \mathrm{mgO}_{2} / \mathrm{L}$, and $\mathrm{BOD}_{5} / \mathrm{COD}$ ratio of 0.3 is quite low. Da Phuoc landfill came into operating in 2007, after over 10 years, the main component of leachate is organic substances, which are difficult or non-biodegradable. Leachate is gradually shifted to the stable phase.

\section{BEF pilot system and operation}

BEF pilot scale model $(30 \times 10 \times 10 \mathrm{~cm})$ divided by a PEM (Nafion ${ }^{\circledR} 112$ ) into two chambers. The volume of each chamber (anode and cathode chambers) was $1.5 \mathrm{~L}$ with a working volume of $1.134 \mathrm{~L}$. Cathode chamber used a graphite electrode, the anode chamber used a carbon fabric electrode with size $(7.5 \mathrm{x} 5 \mathrm{x}$ $0.4 \mathrm{~cm}$ ). The electrodes connected with copper wire of $2 \mathrm{~mm}$ diameter and $40 \mathrm{~cm}$ length through an external transistor of $100 \Omega$ and DC supply with voltage 0 $30 \mathrm{~V}$, current $0-5 \mathrm{~A}$ to adjust to each test requirement (Figure 1a, c).

At the first stage of the survey, anode chamber was loaded with anaerobic sludge and $500 \mathrm{~mL}$ of artificial wastewater (glucose $30 \mathrm{~g} / \mathrm{L}, \mathrm{KH}_{2} \mathrm{PO}_{4} 4.33 \mathrm{~g} / \mathrm{L}$, $\left.\mathrm{Na}_{2} \mathrm{HPO}_{4} 2 \mathrm{~g} / \mathrm{L}, \mathrm{NH}_{4} \mathrm{Cl} 0.2 \mathrm{~g} / \mathrm{L}, \mathrm{KCl} 0.13 \mathrm{~g} / \mathrm{L}\right)^{1}$ to help anaerobic microorganisms grow and develop stably. The microorganisms decompose glucose to $\mathrm{H}^{+}$ and produce electrons (Equation (1)):

$$
\mathrm{C}_{6} \mathrm{H}_{12} \mathrm{O}_{6}+6 \mathrm{H}_{2} \mathrm{O} \rightarrow 6 \mathrm{CO}_{2}+24 \mathrm{H}^{+}+24 \mathrm{e}^{-}
$$

Then ion $\mathrm{H}^{+}$passed through the PEM to the cathode chamber. Due to the potential difference in voltage, electrons formed at the anode chamber will transfer the external resistor and to the cathode electrode. In the cathode chamber, the pump supplies oxygen for the reaction (Equation (2)) to form $\mathrm{H}_{2} \mathrm{O}_{2}$. The amount of $\mathrm{H}_{2} \mathrm{O}_{2}$ produced will immediately react with the amount of Fe (II) added to form hydroxyl radicals $\left({ }^{\bullet} \mathrm{OH}\right)$ (Equation (3)) which oxidize persistent organic compounds in leachate (Equation (4)).
In addition, the energy generated helps restore $\mathrm{Fe}^{2+}$ (Equation (5)).

$$
\begin{gathered}
\mathrm{O}_{2}+2 \mathrm{H}^{+}+2 \mathrm{e} \rightarrow \mathrm{H}_{2} \mathrm{O}_{2} \\
\mathrm{H}_{2} \mathrm{O}_{2}+\mathrm{Fe}^{2+} \rightarrow \bullet \mathrm{OH}+\mathrm{OH}+\mathrm{Fe}^{3+} \\
\bullet \mathrm{OH}+\mathrm{RP} \rightarrow \text { oxidation products }\left(\mathrm{CO}_{2}, \mathrm{H}_{2} \mathrm{O}\right) \\
\mathrm{Fe}^{3+}+\mathrm{e}^{-} \rightarrow \mathrm{Fe}^{2+}
\end{gathered}
$$

All chemicals and reagents used for the experiments were of analytical grade and supplied by Merck (Germany). In each experiment, $500 \mathrm{~mL}$ of leachate was added at the cathode chamber, $\mathrm{pH}$ was adjusted using $\mathrm{NaOH} 1 \mathrm{~N}, \mathrm{H}_{2} \mathrm{SO}_{4} 1 \mathrm{~N}$. The agents used in the Fenton process includes $\mathrm{FeSO}_{4} \cdot 7 \mathrm{H}_{2} \mathrm{O}$ \%\%. All experiments were performed at $30^{\circ} \mathrm{C}$ temperature and atmospheric pressure in a batch mode manner. Data are representative with three replicates and their average are reported.

\section{Chemical analysis}

$\mathrm{pH}$ value of wastewater was measured by Schott - LAB 850 - Germany. The parameters COD, $\mathrm{BOD}_{5}$, Total Phosphor, Total Nitrogen, and TSS were determined according to the Standard Methods for the examination of water and wastewater ${ }^{2}$.

$\mathrm{COD}, \mathrm{BOD}_{5}$ were observed throughout the experiment. For the Bicromate method, the amount of residual $\mathrm{H}_{2} \mathrm{O}_{2}$ and $\mathrm{Fe}^{2+}$ in sample after the reaction affect the results of COD determination according to the reaction (Equations (6) and (7)) ${ }^{3}$.

$$
\begin{gathered}
\mathrm{Cr}_{2} \mathrm{O}_{7}^{2-}+3 \mathrm{H}_{2} \mathrm{O}_{2}+8 \mathrm{H}^{+} \rightarrow 2 \mathrm{Cr}^{3+}+ \\
3 \mathrm{O}_{2}+7 \mathrm{H}_{2} \mathrm{O} \\
\mathrm{Cr}_{2} \mathrm{O}_{7}^{2-}+\mathrm{Fe}^{2+}+\mathrm{H}^{+} \rightarrow \mathrm{Cr}^{3+}+\mathrm{Fe}^{3+}+\mathrm{H}_{2} \mathrm{O}
\end{gathered}
$$

In this study, reaction in sample after treatment will be stopped immediately by adding $\mathrm{NaOH} 2.5 \mathrm{~N}$ to $\mathrm{pH} 10$ - 11 to precipitate iron, then heat at $70-80^{\circ} \mathrm{C}$ within 30 minutes to completely remove residual $\mathrm{H}_{2} \mathrm{O}_{2}$ before conducting COD analysis ${ }^{4}$.

\section{Data processing}

- Processing efficiency (H\%) is calculated according to the formula:

$$
H=\frac{C_{0}-C}{C_{0}} * 100
$$

Where: $\mathrm{C}_{0}$ is the initial concentration $(\mathrm{mg} / \mathrm{L})$ $\mathrm{C}$ is the final concentration $(\mathrm{mg} / \mathrm{L})$ 
Table 1: Composition, characteristics of Da Phuoc leachate

\begin{tabular}{llll}
\hline Parameter & Unit & Result & $\begin{array}{l}\text { Viet Nam National Technical Regula- } \\
\text { tion }-25: 2009 / \text { MONRE Column B1 }\end{array}$ \\
$\mathrm{pH}$ & - & 7.8 & - \\
$\mathrm{BOD}_{5}$ & $\mathrm{mgO}_{2} / \mathrm{L}$ & $1500 \pm 59.7$ & 100 \\
$\mathrm{COD}$ & $\mathrm{mgO}_{2} / \mathrm{L}$ & $4950 \pm 14$ & 400 \\
$\mathrm{BOD}_{5} / \mathrm{COD}$ & - & 0.3 & - \\
Total Phosphor & $\mathrm{mg} / \mathrm{L}$ & $12.4 \pm 0.43$ & - \\
{$[\mathrm{Fe}]$ total } & $\mathrm{mg} / \mathrm{L}$ & $44.1 \pm 2.24$ & - \\
Total Kjeldahl Nitrogen & $\mathrm{mg} / \mathrm{L}$ & $1477 \pm 62.6$ & 60 \\
Ammonium & $\mathrm{mg} / \mathrm{L}$ & $589.67 \pm$ & 25 \\
& & 22.11 & \\
Total Suspended Solid & $\mathrm{mg} / \mathrm{L}$ & 15.3 & - \\
\hline
\end{tabular}

(a)
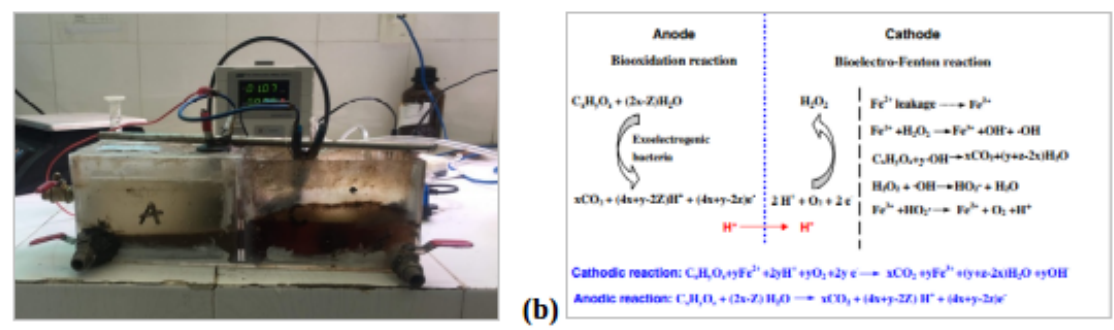

(b)

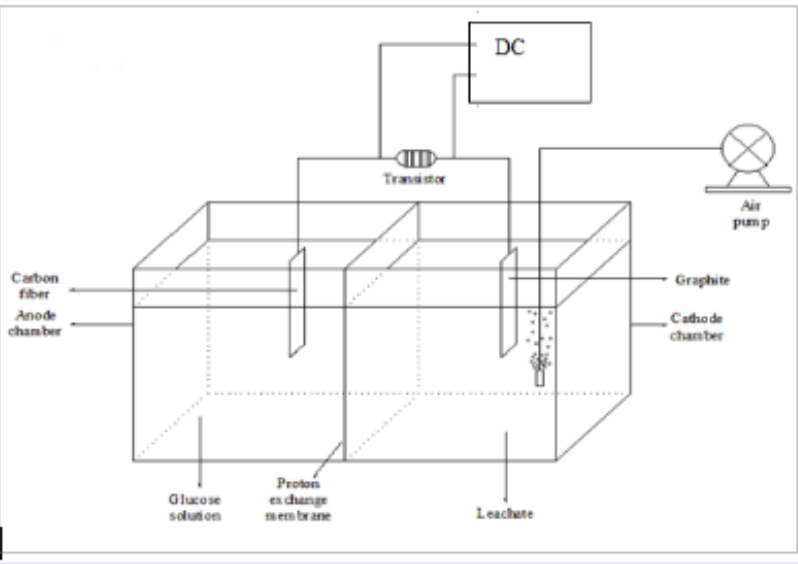

Figure 1: (a) Photograph (b) Electro transfer mechanism in the BEF system (c)Schematic drawing of the experimental setup of the BEF system 


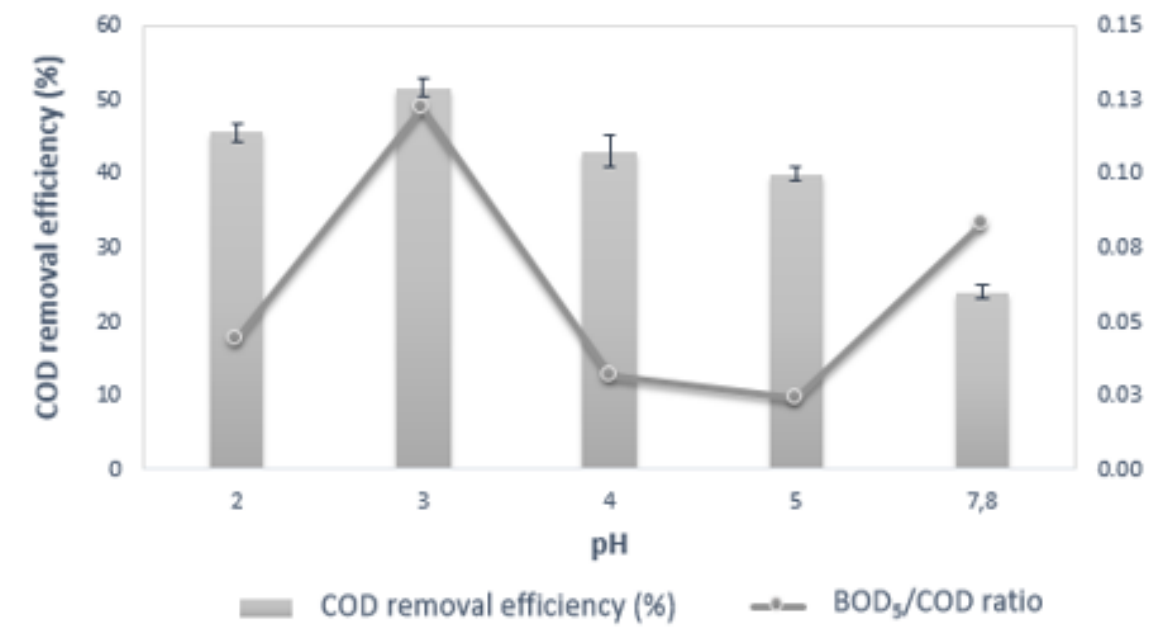

Figure 2: COD removal efficiency (\%) $( \pm \mathrm{SD})$ and $\mathrm{BOD}_{5} / \mathrm{COD}$ ratio of treated leachate following various $\mathrm{pH}$ in cathode chamber onthe Bio-Electro-Fenton process. Reaction conditions: $\left[\mathrm{Fe}^{2+}\right]=1.4 \mathrm{~g} / \mathrm{L}$, reaction time 60 minutes, current intensity $=1 \mathrm{~A}$, airflow $=4 \mathrm{~L}_{\text {air }}$ /minute

\section{RESULTS}

To determine the maximum treatment efficiency of the method for leachate as well as evaluate the influence of important parameters in the BEF model, experiments are performed to optimize each parameter in a complex matrix of effects. The result show similarity to other Fenton processes, the optimal $\mathrm{pH}$ of $\mathrm{BEF}$ is at 3 (Figure 2).

A larger concentration of $\mathrm{Fe}^{2+}$ catalyst will increase COD treatment efficiency significantly, up to $4 \mathrm{~g} / \mathrm{L}$. However, when concentration is too high, it will reduce processing efficiency. Treatment efficiency tends to decrease at increasing iron concentration (Figure 3). The COD removal efficiency decreased from $54.82 \pm 2.04 \%$ to $51.22 \pm 1.53 \%$, while the $\mathrm{BOD}_{5} / \mathrm{COD}$ ratio increased when concentration $\left[\mathrm{Fe}^{2+}\right]$ increased from $1 \mathrm{~g} / \mathrm{L}$ to $1.4 \mathrm{~g} / \mathrm{L}$, respectively. When the concentration $\left[\mathrm{Fe}^{2+}\right]$ is from $1.4 \mathrm{~g} / \mathrm{L}$ to 4 $\mathrm{g} / \mathrm{L}$, the treatment efficiency increases linearly with $\left[\mathrm{Fe}^{2+}\right]$. The $\mathrm{BOD}_{5} / \mathrm{COD}$ ratio reached the highest values of 0.15 at $3 \mathrm{~g} / \mathrm{L}$ and the lowest value of 0.04 at $6 \mathrm{~g} / \mathrm{L}$.

For current intensity, the addition of an external current to the system helps to accelerate the Fenton process due to electrons are increased with electrons made from anaerobic organisms decompose glucose in the anode chamber. The optimum current for the system is recorded at $1 \mathrm{~A}$ (Figure 4).

The reaction time and airflow rate provided to the system were also surveyed. (Figures 5 and 6 ) The reac- tion time of 60 minutes, the airflow rate of $12 \mathrm{~L} / \mathrm{min}$ yiel ded the highest COD removal efficiency, reaching $62.42 \pm 0.99 \%$ and $68.20 \pm 1.04 \%$, respectively.

\section{DISCUSSION}

\section{Effect of pH on the Bio-Electro-Fenton pro- cess}

Both of case $\mathrm{pH}$ is too low and too high are effect to the efficiency of the Fenton process ${ }^{4}$. The Fenton process can be inhibited because of very low $\mathrm{pH}$ values $(\mathrm{pH}<3) . \mathrm{Fe}^{2+}$, which exists as $\mathrm{Fe}\left[\mathrm{H}_{2} \mathrm{O}_{6}\right]^{2+}$, has a slower reaction rate with $\mathrm{H}_{2} \mathrm{O}_{2}$ than $\mathrm{Fe}\left[\mathrm{H}_{2} \mathrm{O}_{5}\right]^{2+}$ at $\mathrm{pH}=3$ which leads to less hydroxyl $(\bullet \mathrm{OH})$ generation ${ }^{5}$. Besides, when the $\mathrm{pH}$ is too low $\mathrm{H}^{+}$will react with $\mathrm{H}_{2} \mathrm{O}_{2}$ to form peroxone $\left(\mathrm{H}_{3} \mathrm{O}_{2}{ }^{+}\right)$according to the reaction $\mathrm{H}_{2} \mathbf{O}_{2}+\mathbf{H}^{+} \rightarrow \mathbf{H}_{3} \mathbf{O}_{2}{ }^{+}$. The peroxone do not react with $\mathrm{Fe}^{2+}$ therefore it will decrease ${ }^{\bullet} \mathrm{OH}$ formation efficiency which leads to reduces the processing efficiency of the Fenton process.

At high $\mathrm{pH}(\mathrm{pH} \geq 4)$, the formation of ferrous/ferric hydroxide complexes leads to the catalyst deactivation, which decreases the quantity of ${ }^{\bullet} \mathrm{OH}^{6}$. In addition, the decomposition of $\mathrm{H}_{2} \mathrm{O}_{2}$ into $\mathrm{H}_{2} \mathrm{O}$ and $\mathrm{O}_{2}$ also increases with increasing $\mathrm{pH}^{7,8}$. The accumulation of protons due to the slow and insufficient protons diffusion through membrane would cause a decrease of $\mathrm{pH}$ in anode chamber ${ }^{6}$. Therefore, the cathode electrode material as a source to self-regulate the supply of $\mathrm{Fe}^{2+}$ under neutral conditions is necessary to reduce the cost of $\mathrm{pH}$ adjusting chemicals. 


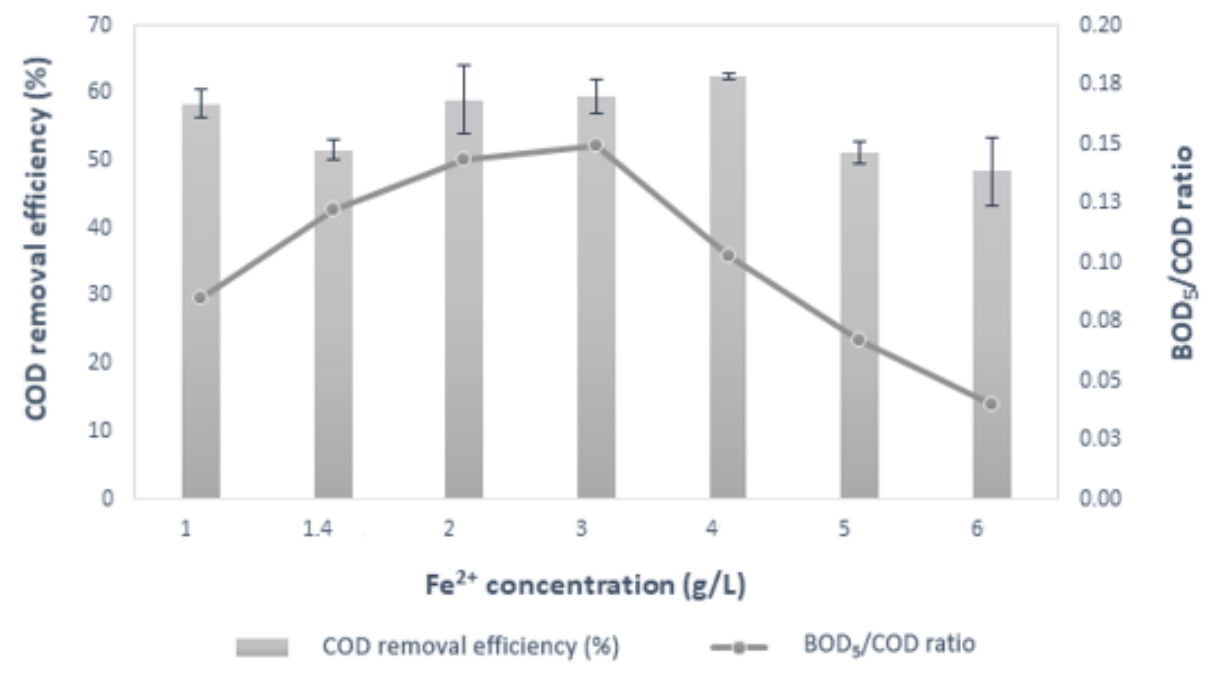

Figure 3: COD removal efficiency (\%) $\left( \pm \mathrm{SD}\right.$ ) and $\mathrm{BOD}_{5} / \mathrm{COD}$ ratio of treated leachate following various $\mathrm{Fe}^{2+}$ concentration in cathode chamber on the Bio-Electro-Fenton process. Reaction conditions: $\mathrm{pH}=3$, reaction time 60 minutes, current intensity $=1 \mathrm{~A}$, airflow $=4 \mathrm{~L}_{\text {air }} /$ minute

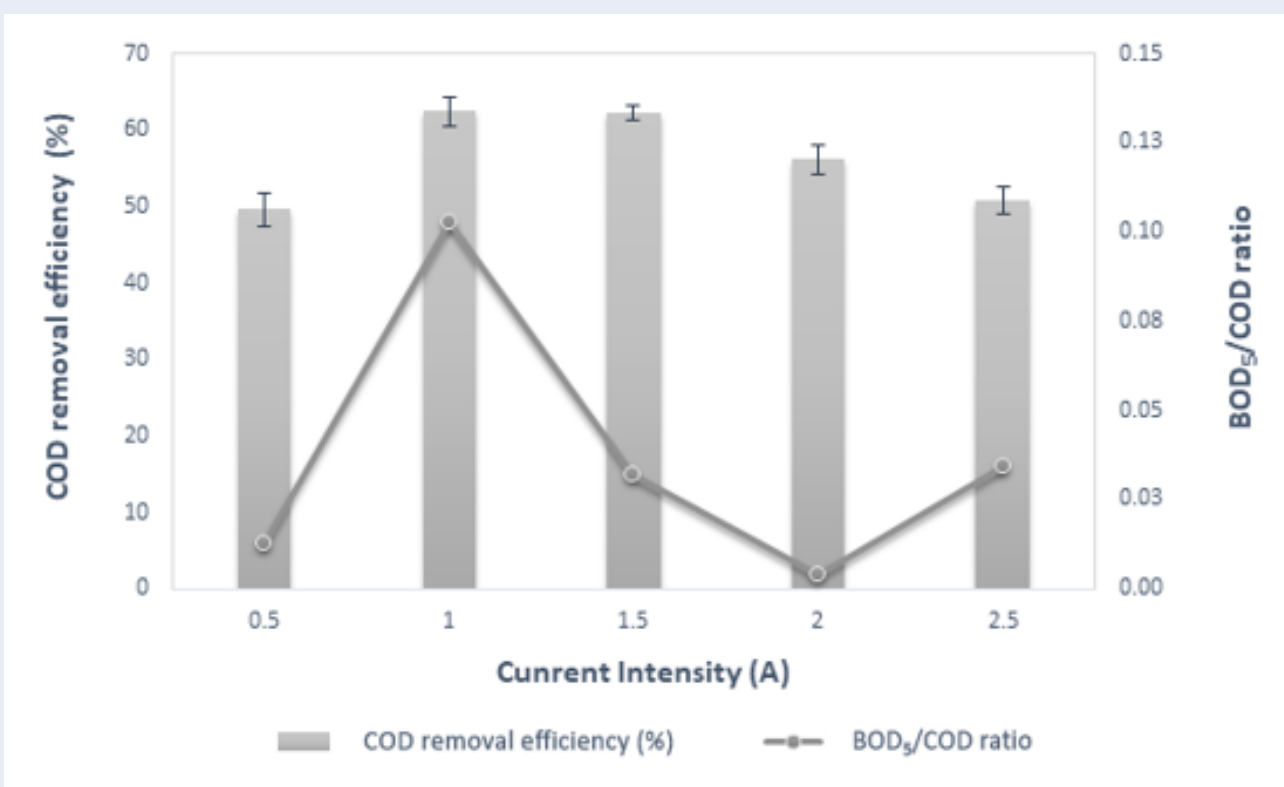

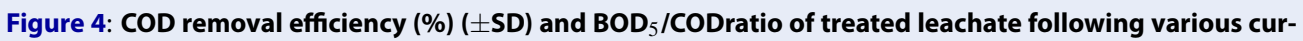
rent intensity incathode chamber on the Bio-Electro-Fenton process. Reaction conditions: $\mathrm{pH}=3$, reaction time 60 minutes, $\left[\mathrm{Fe}^{2+}\right]=4 \mathrm{~g} / \mathrm{L}$, airflow $=4 \mathrm{~L}_{\text {air }} /$ minute 


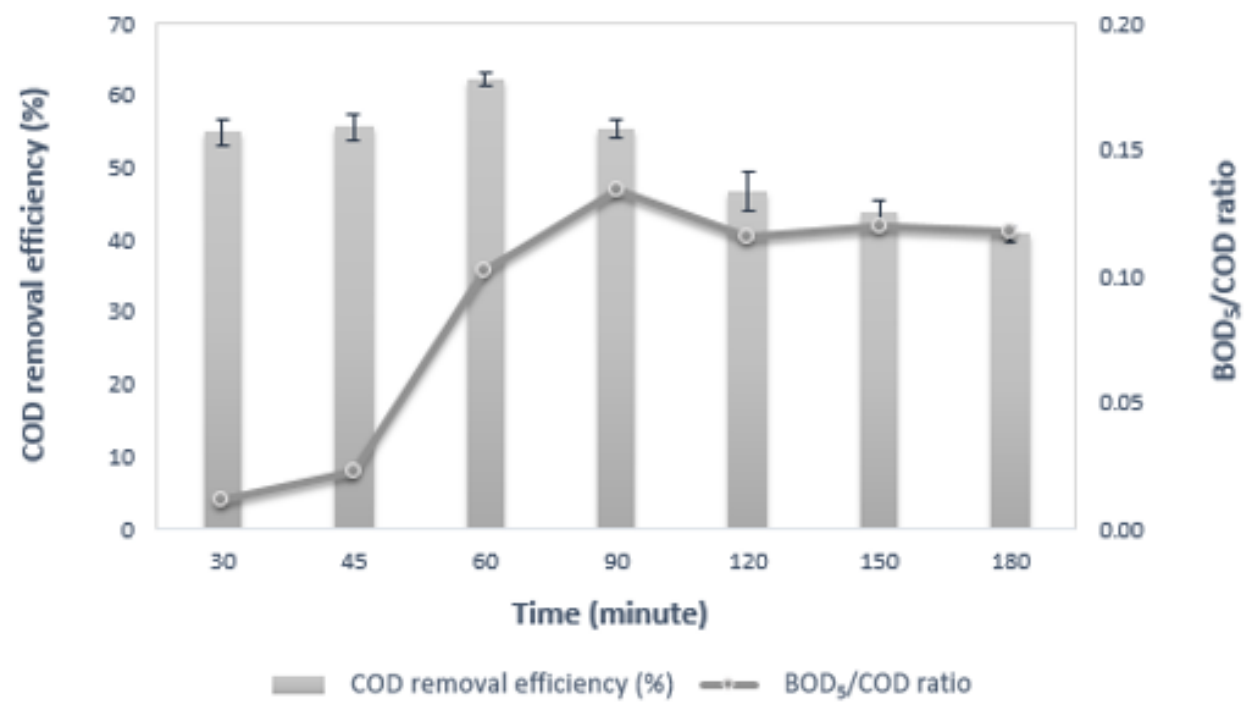

Figure 5: COD removal efficiency (\%) $( \pm \mathrm{SD})$ and $\mathrm{BOD}_{5} / \mathrm{COD}$ ratio of treated leachate following various reaction times on the Bio-Electro-Fenton process. Reaction conditions: $\mathrm{pH}=3,\left[\mathrm{Fe}^{2+}\right]=4 \mathrm{~g} / \mathrm{L}$, current intensity = $1 \mathrm{~A}$, airflow $=4 \mathrm{~L}_{\text {air }} /$ minute

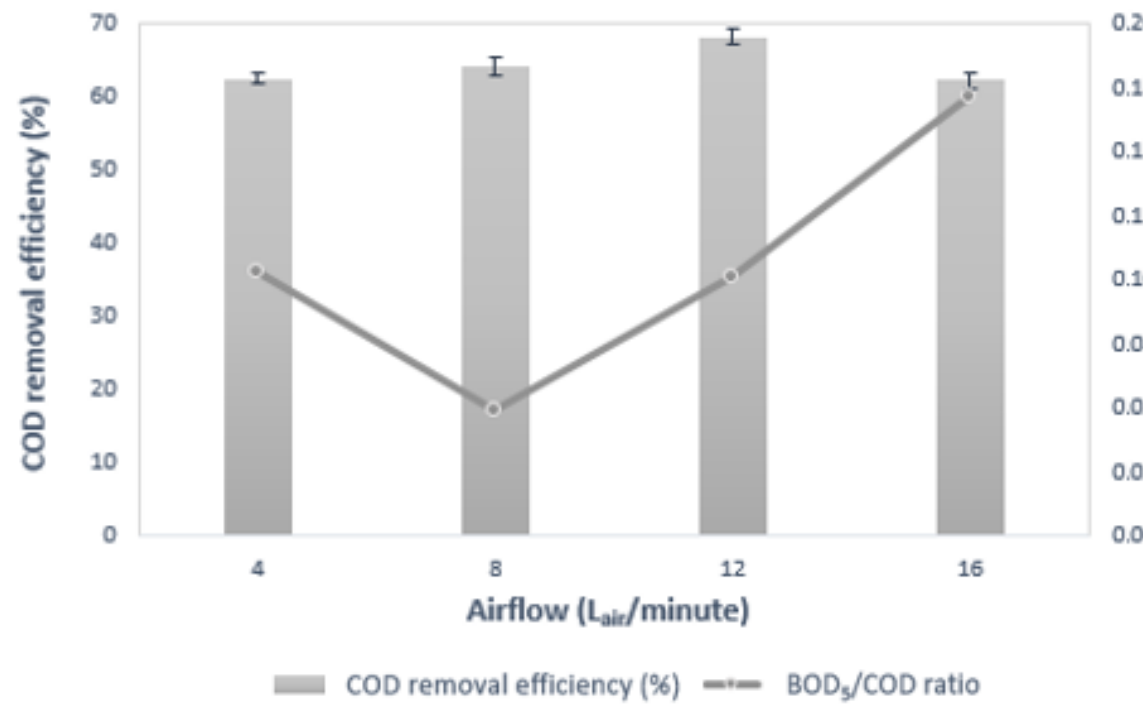

Figure 6: COD removal efficiency (\%) $( \pm S D)$ and $\mathrm{BOD}_{5} / \mathrm{COD}$ ratio of treated leachate following various airflow into cathode chamber on the Bio-Electro-Fenton process. Reaction conditions: $\mathrm{pH}=3,\left[\mathrm{Fe}^{2+}\right]=4 \mathrm{~g} / \mathrm{L}$, reaction time 60 minutes, current intensity $=1 \mathrm{~A}$ 
Effect of $\left[\mathrm{Fe}^{2+}\right]$ on the Bio-Electro-Fenton process

$\mathrm{Fe}^{2+}$ is an extremely important factor that directly affects the Fenton process. Considering that the $\mathrm{H}_{2} \mathrm{O}_{2}$ production rate and yield could be constant at defined conditions in bio-electro-chemical system, $\mathrm{Fe}^{2+}$ as catalyst could be a key factor for the final treatment performance ${ }^{9}$. As a result, a certain amount of $\mathrm{Fe}^{2+}$ saves chemicals and makes the process more efficient. At low $\left[\mathrm{Fe}^{2+}\right]$ concentration, hydroxyl $(\bullet \mathrm{OH})$ produced just enough to oxidize the biodegradable organic compounds. When the dose of $\mathrm{Fe}^{2+}$ increased, amount of hydroxyl is more produced. The oxidation of organics with ${ }^{\bullet} \mathrm{OH}$ occurs through well-known pathways, principally $\mathrm{H}$ atom abstraction (mainly from aliphatics) and addition to $\mathrm{C}=\mathrm{C}$ bonds (mainly with aromatics leading to the formation of hydroxylated aromatic derivatives) $)^{10}$. The persistent organics changes into a biodegradable form, increasing the $\mathrm{BOD}$ value, increasing the $\mathrm{BOD}_{5} / \mathrm{COD}$ ratio and leading to a reduction in processing efficiency.

At higher concentration $\left[\mathrm{Fe}^{2+}\right]$, from $4 \mathrm{~g} / \mathrm{L}$ to $6 \mathrm{~g} / \mathrm{L}$, treatment efficiency decreases due to reduction of radicals ${ }^{\bullet} \mathrm{OH}$ according to the reaction (Equation (8) ${ }^{11}$ :

$$
\cdot \mathrm{OH}+\mathrm{Fe}^{2+} \rightarrow \mathrm{Fe}^{3+}+\mathrm{OH}^{-}
$$

In addition, the $\mathrm{Fe}^{3+}$ ions formed can react with $\mathrm{H}_{2} \mathrm{O}_{2}$ to reduce the mineralization of organic substances (Equation (9) $)^{12}$ :

$$
\mathrm{H}_{2} \mathrm{O}_{2}+\mathrm{Fe}^{3+} \rightarrow \mathrm{Fe}^{2+}+{ }^{\bullet} \mathrm{OOH}+\mathrm{H}^{+}
$$

Excess iron salts increase the amount of dissolved salt (TDS) and conductivity. Besides, after stopping the reaction, treated wastewater must be adjusted to neutral pH. $\mathrm{pH}$ raising create a large amount of iron deposits in the sludge ${ }^{12}$.

\section{Effect of current intensity on the Bio- Electro-Fenton process}

The current intensity produced by the microorganism system in the cathode chamber to create $\mathrm{H}_{2} \mathrm{O}$, which is an extremely important catalyst in the BEF. Higher current will increase the amount of $\mathrm{H}_{2} \mathrm{O}_{2}$, thus increasing the number of $\left({ }^{\bullet} \mathrm{OH}\right)$ hydroxyl radicals in the electrolyte environment. However, in the experiments, the efficiency of the current generation by the microorganism system was quite low, therefore to increase the processing efficiency, the experiment used an external power (DC) to connect the BEF system to supplement the process. The technology converts from microbial electrolysis cells (MEC) to the microbial fuel cell (MFC). Besides, increasing the current too high will affect processing efficiency while wasting a significant amount of energy. In this case, optimized current intensity is usually chosen to attain the maximum $\mathrm{H}_{2} \mathrm{O}_{2}$ production rate and yield, and its value quite depends on the cathode material used ${ }^{6}$.

The current increased (0,5 to $1 \mathrm{~A})$ with the increasing rate of pollutant degradation $(49.60 \pm 2.17 \%$ to $62.42 \pm 1.81 \%$ ) since more $\mathrm{H} \mathrm{O}$ are formed at a given time. However, the COD concentration decreased as the current increased above $1 \mathrm{~A}$, the efficiency decreased from $62.42 \pm 1.81 \%$ to $50.75 \pm 1.72 \%$ at 2.5A. The current cannot be increased indefinitely since the cathode potential would be changed by the applied voltage, resulting in the side reactions, and thereby decreasing current efficiency and pollutants removal efficiency. The side reactions can involve: (i) high current density by adding high external voltage would enhance the $\mathrm{H}_{2} \mathrm{O}_{2}$ electrochemical reduction through (Equation (10)), (ii) the $\mathrm{H}_{2} \mathrm{O}_{2}$ reaction with $\mathrm{Fe}^{3+}$ via (Equation (11)) and (Equation (12)) (iii) the destruction of ${ }^{\bullet} \mathrm{OH}$ with $\mathrm{H}_{2} \mathrm{O}_{2}$ and $\mathrm{Fe}^{2+}$ via (Equation (13)) and (Equation (8) $)^{6}$, (iv) The reactions forming $\mathrm{H}_{2}$ at the cathode are more dominant via (Equation (14)) ${ }^{4}$.

$$
\begin{gathered}
\mathrm{H}_{2} \mathrm{O}_{2}+2 \mathrm{H}^{+}+2 \mathrm{e}^{-} \rightarrow 2 \mathrm{H}_{2} \mathrm{O} \\
\mathrm{Fe}^{3+}+\mathrm{H}_{2} \mathrm{O}_{2} \rightarrow \mathrm{Fe}^{2+}+\mathrm{HO}_{2}^{\bullet}+\mathrm{H}^{+} \\
\mathrm{Fe}^{3+}+\mathrm{HO}_{2}^{\bullet} \rightarrow \mathrm{Fe}^{2+}+\mathrm{O}_{2}+\mathrm{H}^{+} \\
\mathrm{H}_{2} \mathrm{O}_{2}+\cdot \mathrm{OH} \rightarrow \mathrm{H}_{2} \mathrm{O}+\mathrm{HO}_{2}^{\bullet} \\
2 \mathrm{H}^{+}+2 \mathrm{e}^{-} \rightarrow \mathrm{H}_{2}
\end{gathered}
$$

\section{Effect of reaction time on the Bio-Electro- Fenton process}

The time needed to complete a Fenton reaction will depend on the many variables such as catalyst dose and wastewater strength. For more complex or more concentrated wastes as leachate, the reaction in various studies fluctuated between 30 minutes and 3 hours ${ }^{13}$.

COD removal efficiency increased gradually and reached the highest of $62.42 \pm 0.99 \%$ at $60 \mathrm{~min}$ utes, $\mathrm{BOD}$ in leachate also increased from $50 \mathrm{mgO}_{2} / \mathrm{L}$ to $191 \mathrm{mgO}_{2} / \mathrm{L}$. The complex organic is decomposed into simpler organic substances, thus reduced COD concentration, increased BOD concentration in wastewater, contributed to an increase $\mathrm{BOD}_{5} / \mathrm{COD}$ 


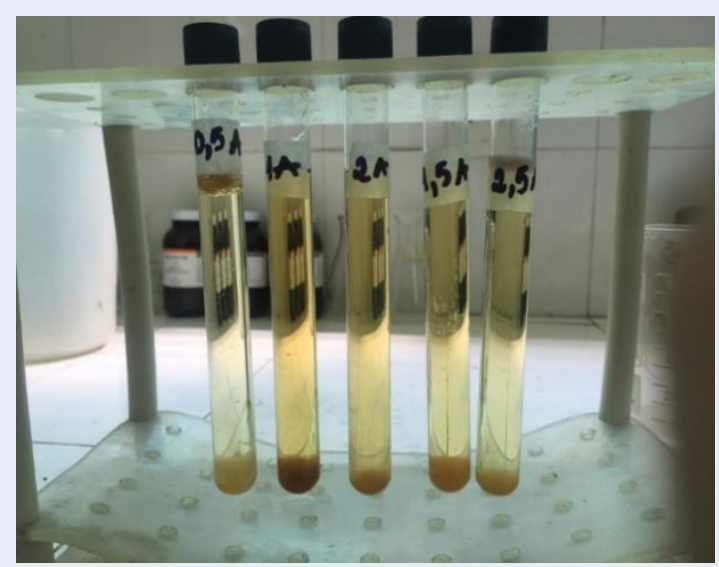

Figure 7: Samples of current intensity after processing

ratio. Increasing the reaction time will create more - $\mathrm{OH}$ radicals to form $\mathrm{H}_{2} \mathrm{O}_{2}$, while also fostering the Fenton reactions occur more to thoroughly oxidize the pollution.

After the equilibrium time, COD concentration decreased, the $\mathrm{BOD}_{5} / \mathrm{COD}$ ratio did not change significantly. The BOD concentration raised, this can be explained by the persistent organic pollutant degradation which still continues to occur but tends to slow down. In addition, intermediates created are more difficult to oxidize, which inhibits the Fenton reaction. The amount of $\mathrm{Fe}^{2+}$ when being regenerated will be oxidized to $\mathrm{Fe}_{2} \mathrm{O}_{3}$, thus reducing treatment efficiency ${ }^{4}$.

\section{Effect of airflow on the Bio-Electro-Fenton process}

Oxy is one of the key parameters in the BEF system, which is the electron acceptor in the cathode chamber to produce $\mathrm{H}_{2} \mathrm{O}_{2}$. High airflow rate could enhance the dissolved oxygen in solution and promote the oxygen mass transfer rate, and thus, is beneficial for $\mathrm{H}_{2} \mathrm{O}_{2}$ production and accumulation in bioelectrochemical systems ${ }^{6}$. It is important to set the optimal airflow rate because if the speed is too low, it will not maintain enough dissolved oxygen and if the speed is too high, it will cost a lot of operating energy for the system.

COD treatment efficiency increased with increasing airflow rate and reached $68.20 \pm 1.04 \%$ (Figure 6) at the maximum airflow rate of $12 \mathrm{~L}$ air/minute. The reason is that the excessive high airflow rate could also disturb the mass transfer between catholyte and electrode and lead to a low catalytic efficiency for pollutants degradation by the Fenton process ${ }^{6}$. The ratio of $\mathrm{BOD}_{5} / \mathrm{COD}$ also increased significantly due to $(\bullet \mathrm{OH})$ hydroxyl free radicals non-selectively reacts with POPs compounds to create more easily biodegradable compounds.

However, when continuing to increase the airflow rate, from 12 to $16 \mathrm{~L}$ air/minute, COD treatment efficiency decreased from $68.20 \pm 1.04 \%$ to $62.22 \pm 1.12$ $\%$, respectively. This is explained by the extremely high airflow rate which leads to a chemical imbalance of reaction (2) $\mathrm{O}_{2}+2 \mathrm{H}^{+}+2 \mathrm{e}^{-} \rightarrow \mathrm{H}_{2} \mathrm{O}_{2}$ and reduces the accumulation of $\mathrm{H}_{2} \mathrm{O}_{2}{ }^{14}$.

\section{CONCLUSIONS}

The results obtained in the study show that the use of the Bio-electro-Fenton process is effective for wastewater with large concentrations and difficult to treat as leachate. At optimal conditions of the model including $\mathrm{pH} 3,\left[\mathrm{Fe}^{2+}\right]=4 \mathrm{~g} / \mathrm{L}$, current intensity $=1 \mathrm{~A}$, reaction time 60 minutes and airflow $=12 \mathrm{LO}_{2} / \mathrm{min}$, as a result COD from $4950 \pm 14 \mathrm{mgO}_{2} / \mathrm{L}$ to $1574.1 \pm$ $51.4 \mathrm{mgO}_{2} / \mathrm{L}$ (decreased $68.2 \pm 1.04 \%$ ). The ratio of $\mathrm{BOD}_{5} / \mathrm{COD}$ decreased from 0.3 to 0.1 due to Fenton reactions which reduced a large amount of easily biodegradable organic matter, suggesting that the appropriate method for pre-treatment processes support to thoroughly eliminate pollutants.

\section{LIST OF ABBREVIATIONS}

AOPs: Advanced oxidation process

BEF: Bio-electro-Fenton

PEM: Proton exchange membrane

POPs: Persistent organic pollutants

\section{AUTHORS' CONTRIBUTIONS}

The author Ho Nhut Linh did the experiment. The author Ho Truong Nam Hai discussed the results and 
wrote the final manuscript. All authors approved the final manuscript.

\section{COMPETING INTERESTS}

The authors declare that they have no competing interests.

\section{ACKNOWLEDGEMENTS}

This study is funded by University of Science, VNU HCM, under grant number T2019 - 30. The author wish to thank Bui Thi Nhu Quynh for revising and editing the English text.

\section{REFERENCES}

1. Birjandi N, Younesi H, Ghoreyshi AA, Rahimnejad M. Electricity generation, ethanol fermentation and enhanced glucose degradation in a bio-electro-Fenton system driven by a microbial fuel cell. Journal of Chemical Technology \& Biotechnology. 2016 Jun;91(6):1868-1876.

2. American Public Health Association. Standard methods for the examination of water and wastewater. 23nd Edition. 2017.

3. Talinli I, Anderson GK. Interference of hydrogen peroxide on the standard COD test. Water Research. 1992 Jan;26(1):107110.

4. Loan NTH, Huy DH, Hien TT, Canh TT. Nghiên cứu tiền xử lý nước rỉ rác bãi chôn lấp Gò Cát, thành phố Hồ Chí Minh bằng phương pháp Fenton truyền thống và Fenton điện hóa." Tạp chí khoa học Đại học Quốc gia Hà Nội. 2018.

5. Gallard H, Laat JD. Kinetic modelling of Fe (III)/H2O2 oxidation reactions in dilute aqueous solution using atrazine as a model organic compound. Water Research. 2000 Aug;34(12):31073116.

6. Li X, Chen S, Angelidaki I, Zhang Y. Bio-electro-Fenton processes for wastewater treatment: Advances and prospects. Chemical Engineering Journal. 2018 Dec;354:492-506.

7. Zhang H, Zhang D, Zhou J, Wang YT. Removal of COD from landfill leachate by Electro-Fenton method. Journal of Hazardous Materials. 2006 Aug;135(1-3):106-111.

8. Nidheesh PV, Gandhimathi R. Trends in electro-Fenton process for water and wastewater treatment: an overview. Desalination. 2012 Aug;299:1-15.

9. Wu JC, Wang CH, Wang CT, Wang CT, Wang YT. Effect of FeSO4 on bio-electro-fenton microbial fuel cells with different exchange membranes. Materials Research Innovations. 2015 May;19(5):S5-1276-S5-1279.

10. Olvera-Vargas H, Trellu C, Oturan N, Oturan MA. Bio-electroFenton: a new combined process-principles and applications. Springer. 2017 Jan;61:29-56.

11. Kang YW, Hwang KY. Effects of reaction conditions on the oxidation efficiency in the Fenton process. Water Research. 2000 Jul;34(10):2786-2790.

12. Gogate $P R$, Pandit $A B$. A review of imperative technologies for wastewater treatment I: oxidation technologies at ambient conditions. Advances in Environmental Research. 2004 Mar;8(3-4):501-551.

13. Ahmadian M, Reshadat S, Yousefi N, Mirhossieni SH, Zare MR, Ghasemi SR, et al. Municipal leachate treatment by Fenton process: effect of some variable and kinetics. Journal of environmental and public health. 2013 Jun;2013.

14. Ling T, Huang B, Zhao M, Yan Q, Shen W. Repeated oxidative degradation of methyl orange through bio-electro-Fenton in bioelectrochemical system (BES). Bioresource technology. 2015 Dec;203:89-95. 